Asian J. Med. Biol. Res. 2017, 3 (1), 140-144; doi: 10.3329/ajmbr.v3i1.32050

\author{
Asian Journal of \\ Medical and Biological Research \\ ISSN 2411-4472 (Print) 2412-5571 (Online) \\ www.ebupress.com/journal/ajmbr
}

\title{
Article \\ Fungicidal seed treatment on germination and seedling vigour of lentil var. BINA Masur-3
}

\author{
A. Rokib and M. S. Monjil* \\ Department of Plant Pathology, Bangladesh Agricultural University, Mymensingh, Bangladesh
}

*Corresponding author: Professor Dr. M. S. Monjil, Department of Plant Pathology, Bangladesh Agricultural University, Mymensingh, Bangladesh. E-mail: smonjil@yahoo.com

Received: 07 March 2017/Accepted: 16 March 2017/ Published: 30 March 2017

\begin{abstract}
Effectiveness of six fungicides viz., Provax-200 (Carboxin+Thiram), Bavistin DF (Carbendazim), Dithane M-45 (Mancozeb), Secure (Mancozeb+Fenamidone), Antracol (propineb) and Daconil (Chlorothalonil) were evaluated to improve seed germination and seedling vigour of lentil variety BINA Masur-3. The experiment was conducted in the Green House of Seed Pathology Centre, Bangladesh Agricultural University, Mymensingh. Positive effect of seed treatment with fungicides on seed germination and seedling vigour of lentil was recorded. At 20 DAS, increased seed germination over control was observed in treated seeds with Deconil (10.40\%) and Antracol (10.00\%) followed by Dithane M-45 (7.20\%). Seeds treated with Deconil and Dithane M-45 produced seedlings with higher shoot length, root length and seedling vigour. At 20 DAS, higher percent increased vigour index over control was found in Dithane M-45 (24.64\%) and Deconil (22.44\%), respectively.
\end{abstract}

Keywords: seed germination; seedling vigour; lentil; fungicide; Daconil

\footnotetext{
1. Introduction

Lentil is a leading pulse in many developing countries including Bangladesh. It can play an important role in fighting hunger and malnutrition and in improving agricultural sustainability. It is highly rich in protein (Erskine and Witcombe, 1984) and a rich source of several essential micronutrients (Fe, Zn, b-carotene) (Bhatty, 1988). In Bangladesh, lentil is cultivated in an area of about 97400 ha with total production of about 1.57 lac ton (2\% of global share) having an average yield of 1.26 ton/ha (BBS, 2016), whereas average yield of the leading pulse producing countries like Canada, India, Australia, Turkey and The United States was 1.63, 1.61, 1.47, 1.42 and 1.49 ton/ha, respectively (FAOSTAT, 2016). The low productivity of lentil in Bangladesh is attributed by many production constraints. Among these, biotic factors particularly diseases play a major role in limiting the yield of lentil. A number of phytopathogenic soil borne as well as seed borne fungi are responsible for disease development which attack plants during seedling to maturity stages and are more destructive at seedling stage (Hoque, 2014).

Every seed is a potential harbor of a wide variety of mycoflora containing both pathogenic and saprophytic microorganisms, both externally and internally (Utobo et al., 2011). These mycoflora deteriorate seed quality, affect viability and reduce germination of seeds, resulting in the production of abnormal seedlings (Islam and Monjil, 2016; Khanzada et al., 2002). The use of effective seed treatments can reduce the severity of these seed borne pathogens. Fungicidal seed treatments control fungi residing on the seed surface or inside the seed and are also effective against pathogens that reside in soil causing seedling diseases. Fungicidal seed treatment controls seed-borne diseases, improves plant stand, seeding vigour and crop yield (Tanweer, 1982; Shah and Jain, 1993; Klich et al., 1994). To increase the production of lentil qualitatively and quantitatively farmer requires quality seeds. Hence, the present investigation was conducted to find out the effect of recently introduced fungicides on seed germination and seedling vigour of lentil.
} 


\section{Materials and Methods}

Seeds of BINA Masur-3 were collected from BINA Regional Research Station, Pabna, Bangladesh during August 2016. Six fungicides viz., Provax-200 (Carboxin+Thiram), Bavistin DF (Carbendazim), Dithane M-45 (Mancozeb), Secure (Mancozeb+Fenamidone), Antracol (propineb) and Daconil (Chlorothalonil) were collected from authorized agrochemical shops in Mymensingh.

Required amount of seeds and fungicide were taken in a conical flask. Then, few drops of sterilized water were added and shaken well with hands for few minutes and then kept open for drying. When the seeds appeared coating with fungicides then 50 seeds were sown in each tray for germination and vigour test.

Germination test was carried out according to ISTA (2003). Plastic trays $(20 \mathrm{~cm} \times 25 \mathrm{~cm})$ were used for this test. The trays were filled with moist sand at field capacity. Eight trays were used for each treatment (fungicide). Fifty seeds were sown in each tray. At 5, 10, 15 and 20 days after sowing, data on germination, shoot length and root length were recorded. At that time ten seedlings for each treatment were randomly selected, and shoot and root length were measured. Vigor index was determined by the following formula given by Baki and Anderson (1972).

Collected data were statistically analyzed using MSTAT-C Computer Package Program. The significance of the difference among the treatments means was estimated by the least significant difference (LSD) test at 5\% level of probability (Gomez and Gomez, 1984).

\section{Results}

\subsection{Efficacy of fungicides on germination of lentil seeds}

Lentil seeds treated with fungicides showed significant increase of seed germination in tray soil at 5, 10,15 and 20 DAS (Table 1). Highest seed germination at 5DAS was observed in seeds treated with Antracol $(83.67 \%)$ followed by Secure (83.00\%) and Dithane M-45 (82.67\%). At 10 and 15 DAS, highest germination was observed when seeds were treated with Antracol followed by Dithane M-45. At 20 DAS, highest seed germination was observed when seeds were treated with Daconil (92.00\%) and Antracol (91.67) which are statistically similar followed by Dithane M-45 (89.33\%). Lowest germination was recorded in control treatment. At 20 DAS, Daconil resulted highest seed germination over control (10.40\%) followed by Antracol (10.00\%) and Dithane M-45 (7.20\%). Seed treatment with Bavistin DF (carbendazim) did not exert good response in increasing seed germination of lentil.

Table 1. Efficacy of fungicides on germination (\%) of lentil var. BINA Masur-3.

\begin{tabular}{|c|c|c|c|c|c|}
\hline \multirow[t]{2}{*}{ Treatments } & \multicolumn{4}{|c|}{ Germination (\%) } & \multirow{2}{*}{$\begin{array}{l}\text { Percent increase germination over } \\
\text { control at } 20 \text { DAS }\end{array}$} \\
\hline & 5DAS & 10DAS & 15DAS & 20DAS & \\
\hline Provax-200 & $70.00 \mathrm{bc}$ & $77.00 \mathrm{~b}$ & $83.00 \mathrm{~b}$ & $85.67 \mathrm{ab}$ & 2.80 \\
\hline Bavistin DF & $63.33 \mathrm{c}$ & $70.00 \mathrm{c}$ & $78.67 \mathrm{c}$ & $84.00 \mathrm{ab}$ & 0.80 \\
\hline Dithane M-45 & $82.67 \mathrm{a}$ & $86.00 \mathrm{a}$ & $87.33 \mathrm{ab}$ & $89.33 \mathrm{ab}$ & 7.20 \\
\hline Secure & $83.00 \mathrm{a}$ & $85.00 \mathrm{a}$ & $87.00 \mathrm{ab}$ & $86.33 \mathrm{ab}$ & 3.60 \\
\hline Antracol & $83.67 \mathrm{a}$ & $88.33 \mathrm{a}$ & 89.67 a & $91.67 \mathrm{a}$ & 10.00 \\
\hline Deconil & $72.67 \mathrm{~b}$ & $77.00 \mathrm{~b}$ & $86.00 \mathrm{ab}$ & $92.00 \mathrm{a}$ & 10.40 \\
\hline Control & 62.67 & 69.00 & $78.00 \mathrm{c}$ & $83.33 \mathrm{ab}$ & - \\
\hline Level of significance & $* *$ & $* *$ & $* *$ & $* *$ & \\
\hline
\end{tabular}

Data were subjected to Duncan's Multiple Range Test (DMRT) using a statistical computer package (MState C). Each value represents the mean and standard deviation of three replications. In a column, figures with same letter or without letter do not differ significantly whereas figures with dissimilar letter differ significantly (as per DMRT). $* \mathrm{P}<0.05$, $* \mathrm{P}<$ 0.01 versus control treatment.

\subsection{Efficacy of fungicides on shoot length, root length and seedling vigour of lentil}

Efficacy of fungicides on shoot length, root length and seedling vigour of lentil was evaluated at 5, 10, 15 and 20 DAS where significant variation was observed among the different treatments (Table $2,3 \& 4$ ). Fungicidal treatments showed little effect on shoot length up to 20 DAS. Reduced shoot length was observed in seedlings treated with Bavistin DF. At 20 DAS, Bavistin DF and Provax-200 treated seedlings produced significantly lower shoot length. In case of root length, highest root length was found when seeds were treated with Daconil followed by Provax-200 and Secure at 5 DAS. At 10, 15 and 20 DAS, seeds treated with Dithane M-45 produced higher root length. Bavistin DF decreased the root length of lentil seedlings.

At 5, 10, 15 and 20 DAS, higher seedling vigour as vigour index was observed by Dithane M-45 and Daconil (Table 4). At 20 DAS, vigour index of lentil ranged from 2242.36-2799.12. Highest Vigour Index was recorded in case of using Dithane M-45 (2799.12) followed by Daconil (2745.54), Antracol (2529.5) and Secure 
(2501.79), while lowest seedling Vigour Index (2242.36) was found in case of control preceded by Bavistin DF. At 20 DAS, highest increased Vigour Index over control was found in Dithane M-45 (24.83\%) followed by Daconil (22.44\%). Lowest percent Vigour Index increased over control was observed by Bavistin DF (2.64\%).

Table 2. Efficacy of fungicides on shoot length $(\mathrm{cm})$ of lentil var. BINA Masur-3.

\begin{tabular}{lllll}
\hline Treatments & \multicolumn{4}{c}{ Shoot length $(\mathbf{c m})$} \\
\cline { 2 - 5 } & 5DAS & 10DAS & $11.63 \mathrm{bc}$ & $12.06 \mathrm{c}$ \\
\hline Provax-200 & $6.70 \mathrm{a}$ & $10.26 \mathrm{a}$ & $11.36 \mathrm{c}$ & $12.22 \mathrm{bc}$ \\
Bavistin DF & $5.41 \mathrm{c}$ & $8.597 \mathrm{~b}$ & $12.60 \mathrm{a}$ & $13.52 \mathrm{a}$ \\
Dithane M-45 & $5.99 \mathrm{bc}$ & $10.09 \mathrm{a}$ & $12.16 \mathrm{abc}$ & $13.74 \mathrm{a}$ \\
Secure & $5.92 \mathrm{bc}$ & $9.913 \mathrm{a}$ & $12.25 \mathrm{ab}$ & $13.24 \mathrm{ab}$ \\
Antracol & $6.75 \mathrm{a}$ & $10.40 \mathrm{a}$ & $11.49 \mathrm{bc}$ & $13.32 \mathrm{ab}$ \\
Deconil & $6.00 \mathrm{bc}$ & $9.823 \mathrm{a}$ & $12.01 \mathrm{abc}$ & $13.49 \mathrm{a}$ \\
Control & $6.32 \mathrm{ab}$ & $10.05 \mathrm{a}$ & $*$ & $*$ \\
Level of significance & $* *$ & $* *$ & $*$ & \\
\hline
\end{tabular}

Data were subjected to Duncan's Multiple Range Test (DMRT) using a statistical computer package (MState C). Each value represents the mean and standard deviation of three replications. In a column, figures with same letter or without letter do not differ significantly whereas figures with dissimilar letter differ significantly (as per DMRT). $* \mathrm{P}<0.05$, $* \mathrm{P}<$ 0.01 versus control treatment.

Table 3. Efficacy of fungicides on root length $(\mathrm{cm})$ of lentil var. BINA Masur-3.

\begin{tabular}{lllll}
\hline Treatments & \multicolumn{3}{c}{ Root length $(\mathbf{c m})$} \\
\cline { 2 - 5 } & 5DAS & 10DAS & 15DAS & 20DAS \\
\hline Provax-200 & $10.05 \mathrm{~b}$ & $11.19 \mathrm{~b}$ & $14.87 \mathrm{ab}$ & $16.04 \mathrm{~b}$ \\
Bavistin DF & $8.00 \mathrm{~d}$ & $9.99 \mathrm{~cd}$ & $12.27 \mathrm{e}$ & $17.18 \mathrm{bc}$ \\
Dithane M-45 & $8.05 \mathrm{~d}$ & $14.07 \mathrm{a}$ & $15.53 \mathrm{a}$ & $15.25 \mathrm{bc}$ \\
Secure & $9.55 \mathrm{~b}$ & $10.78 \mathrm{bc}$ & $13.73 \mathrm{bcd}$ & $14.33 \mathrm{~cd}$ \\
Antracol & $8.74 \mathrm{c}$ & $10.59 \mathrm{bc}$ & $13.11 \mathrm{cde}$ & $16.51 \mathrm{ab}$ \\
Deconil & $10.81 \mathrm{a}$ & $10.91 \mathrm{bc}$ & $14.25 \mathrm{abc}$ & $13.39 \mathrm{~d}$ \\
Control & $8.21 \mathrm{~cd}$ & $9.31 \mathrm{~d}$ & $12.54 \mathrm{de}$ & $* *$ \\
Level of significance & $* *$ & $* *$ & $* *$ & \\
\hline
\end{tabular}

Data were subjected to Duncan's Multiple Range Test (DMRT) using a statistical computer package (MState C). Each value represents the mean and standard deviation of three replications. In a column, figures with same letter or without letter do not differ significantly whereas figures with dissimilar letter differ significantly (as per DMRT). $* \mathrm{P}<0.05$, *P $<$ 0.01 versus control treatment.

Table 4. Efficacy of fungicides on Vigour Index of lentil var. BINA Masur-3.

\begin{tabular}{|c|c|c|c|c|c|}
\hline \multirow[t]{2}{*}{ Treatments } & \multicolumn{4}{|c|}{ Vigour Index } & \multirow{2}{*}{$\begin{array}{l}\text { Percent increased } \\
\text { Vigour Index over } \\
\text { control at } 20 \text { DAS }\end{array}$} \\
\hline & 5DAS & 10DAS & 15DAS & 20DAS & \\
\hline Provax-200 & $1170.14 \mathrm{a}$ & $1650.72 \mathrm{~cd}$ & $2201.21 \mathrm{~b}$ & $2401.87 \mathrm{c}$ & 7.11 \\
\hline Bavistin DF & 849.26 b & $1302 \mathrm{e}$ & $1858.97 \mathrm{c}$ & $2301.6 \mathrm{c}$ & 2.64 \\
\hline Dithane M-45 & $1160.29 \mathrm{a}$ & $2080.37 \mathrm{a}$ & $2457.75 \mathrm{a}$ & $2799.12 \mathrm{a}$ & 24.83 \\
\hline Secure & $1284.43 \mathrm{a}$ & $1759.90 \mathrm{bc}$ & $2255.37 \mathrm{~b}$ & $2501.79 \mathrm{bc}$ & 11.57 \\
\hline Antracol & $1294.58 \mathrm{a}$ & $1853.42 \mathrm{~b}$ & $2274.52 b$ & $2529.9 \mathrm{abc}$ & 12.82 \\
\hline Deconil & $1225.27 \mathrm{a}$ & $1597.67 \mathrm{~d}$ & $2212.23 \mathrm{~b}$ & $2745.54 \mathrm{ab}$ & 22.44 \\
\hline Control & $911.30 \mathrm{~b}$ & $1338.77 \mathrm{e}$ & $1915.50 \mathrm{c}$ & $2242.36 \mathrm{c}$ & - \\
\hline Level of significance & $* *$ & $* *$ & $* *$ & $* *$ & \\
\hline
\end{tabular}

Data were subjected to Duncan's Multiple Range Test (DMRT) using a statistical computer package (MState C). Each value represents the mean and standard deviation of three replications. In a column, figures with same letter or without letter do not differ significantly whereas figures with dissimilar letter differ significantly (as per DMRT). $* \mathrm{P}<0.05$, *P $<$ 0.01 versus control treatment. 


\section{Discussion}

Lentil seeds treated with fungicides showed significant increase of germination at 5, 10, 15 and 20 DAS. At 5, 10 and 15 DAS, highest germination was observed in seeds treated with Antracol followed either by Dithane M45 or Deconil or vice-versa. At 20 DAS, Deconil resulted highest seed germination over control (10.40\%) followed by Antracol and Dithane M-45. Bavistin DF (carbendazim) showed little response in increasing seed germination of lentil. Jayale et al. (2015) reported that Antracol, Mancozeb and Daconil increased seed germination of chick pea under pot culture condition. Rahman et al. (2012) noted that Maximum germination (85.53\%) of cowpea was achieved when seeds were treated with Provax-200 @ $0.25 \%$ followed by Bavistin 50 WP @ $0.25 \%$. Morshed et al. (2014) found increased germination of chickpea by treating seeds with secure 600WG $(48.62 \%)$ followed by provax-200WP (44.38\%) over control. Andrabi et al. (2011) found that Seed treatment with Carbendazim increased seed germination (71.24\%) in chickpea, though it was at par with Carbendazim + Mancozeb (62.21\%) and Mancozeb (61.46\%). Matus and Slinkard (1993) found that Vitaflo 280 (Vitavax + Thiram) increased seedling emergence $(23 \%)$ of field pea as compared to the untreated control. Hoque et al. (2012) reported enhanced germination (\%) of lentil was in Secure 600wg (0.2\%) treated seeds. Islam et al. (2005) reported that Vitavax-200 is most effective at the lowest concentration in increasing germination of lentil seeds. However, there is no information available in most journals in Bangladesh and online sources regarding the performance of Antracol and Daeconil on germination in lentil. Therefore, seed treatment with Antracol, Dithane M-45 and Daconil might be useful in increasing germination of lentil seed significantly. Antracol or Daconil can be used as a good substitute of commonly known seed treating chemicals like Provax-200, Bavistin DF, Dithane M-45, and Secure.

Efficacy of different fungicides on shoot length, root length and seedling vigour of lentil under green house condition was evaluated and highest shoot length was obtained when seeds were treated with Secure followed by Dithane M-45. Highest root length was obtained when seeds were treated with Dithane M-45 followed by Daconil. Morshed et al. (2014) reported that maximum shoot length $(11.78 \%)$ of chickpea was found when seeds were treated with Secure 600WG, while maximum root length $(21.80 \%)$ was recorded when seeds were treated with Provax 200WP over control. Alrajhi (2014) reported that root length and shoot length of maize was increased with increasing concentrations of Dithane M-45.

In respect of seedling vigor test of lentil seeds a wide range of variation was found significantly. Maximum vigor index was observed in Dithane M-45 followed by Daconil and minimum was recorded in untreated control. Present findings are in accordance with the observation of Alrajhi (2014), who published that the increase in vigor index was significant at different concentration of Dithane M-45 fungicides as compared to control. Doyle et al. (2001) also reported similar findings that seedlings treated with thiamethoxam had a particular advantage of improved seedling vigor

It is noticeable that Bavistin DF (Carbendazim) and untreated control resulted almost similar shoot length, root length and seedling Vigour Index. Ineffectiveness of carbendazim on Vigour Index of lentil might be due to its suppressive effect. Windham and Windham (2004) indicated that systemic fungicides which are based on sterol biosynthesis inhibitor are closely related to plant growth regulators, the use of which at higher than labeled rates shorten the internodes which may lead to slow shoot growth.

\section{Conclusions}

It can be concluded that there is positive effect of seed treatment with fungicides on seed germination and Vigour Index of lentil. Seed treatments with Antracol (Propineb), Daconil (Chlorothalonil), Dithane M-45 and Secure (Mancozeb+Fenamidone) resulted better germination and seedling Vigour Index of lentil over control.

\section{Conflict of interest}

None to declare.

\section{References}

Alrajhi AMH, 2014. Effects of Amistar and Dithane M-45, a systemic fungicide, on Growth Parameters and antioxidative enzymes of Maize (Zea mays L.). Research \& Reviews: J. Bot. Sci., 3:13-19.

Andrabi M, A Vaid and VK Razdan, 2011. Evaluation of different measures to control wilt causing pathogens in chickpea. J. Plant Prot. Res., 51: 55-59.

Bakhsh A, A Ghafor, Z Mubeir and SM Iqbal, 1991. Genotpy interaction for grain yield in lentil. Pakistan J. Agric. Res., 12: 102-105.

Baki AA and JD Anderson, 1972. Physiological and Biological Deterioration of Seeds. In: Seed Biology, Vol. 2: T T Kozlowski (Ed.), Academic Press, New York, pp. 283-315. 
BBS (Bangladesh Bureau of Statistics), 2016. Yearbook of Agricultural Statistics-2015 (27 $7^{\text {th }}$ series), pp. 97.

Bhatty RS, 1988. Composition and quality of lentil (Lens culinaris Medik.): A review. Canadian Institute of Food Science and Technology, 21:144-160.

Doyle P, M Stypa, F Schneidersmann and R Ramachandran, 2001. New generation seed treatment products for canola (Brassica napus, B. campestris) and mustard (Sinapsis alba, Brassica juncea). British crop protection council Symposium proceedings. 76:173-180.

Erskine W and J R Witcombe, 1984. Lentil germplasms catalog ICARDA, Aleppo, Syria.

FAO, 2016. FAOSTAT database collections. Food and Agriculture Organization of the United Nations. Rome.

Gomez KA and AA Gomez 1984: Statistical Procedures for Agricultural Research (second edition). John Wiley and Sons, New York.

Hoque MA, 2012. Effect of Some Fungicides on Foot and Root Rot of Lentil. MS Thesis, Department of Plant Pathology, Bangladesh Agricultural University, Mymensingh.

Hoque MA, I Hamim, MR Haque, MA Alil and M Ashrafuzzaman, 2014. Effect of some fungicides on foot and root rot of lentil. Universal J. Plant Sci., 2: 52-56.

Islam MS and MS Monjil, 2016. Effect of seed washing either alone or in combination with garlic extract and Knowin 50WP on quality of jute seeds. Asian J. Med. Biol. Res., 2: 318-323.

Islam MN, MG Raihan, IH Mian and N Sultana, 2005. Integration of biological and chemical control for seedling mortality of wheat caused by Sclerotium rolfsii. Bangladesh J. Agric. Res., 30: 329-339.

ISTA (International Seed Testing Association), 2001. International Rules of Seed Testing Association. Proc International Seed Testing Association. pp. 180.

ISTA (International Seed Testing Association), 2003. International rules for seed testing, 2003 (Draper, SR Eds.) Zurich, Switezerland, ISTA, pp. 1-121.

Jayale ST, UK Khare, PW Nemade, 2015. Studies on collar rot of chickpea caused by Sclerotium rolfsii Sacc. In: Compendium of 2nd International Conference on Biosecure and stress management. ANGRAU \& PJTSAU, Hyderabad 7-10 January, 2015.

Khanzada KA, MA Rajput, GS Shah, AM Lodhi and F Mehboob, 2002. Effect of seed dressing fungicides for the control of wheat roots. Appl. Soil. Ecol., 13: 271-282

Klich MA, KS Arthur, AL Lax and JM Blade, 1994. A potential new fungicide for stored grains. Mycopathol., 127: 123-127.

Matus A and AE Slinkard, 1993. Effect of fungicidal seed treatment on zero-tannin lentil. Lens Newsletter, 20: 46-50.

Morshed MG, MA Kashem, I Hossain, MY Rafi and MA Latif, 2014. Effect of fungicides in controlling root rot (Fusarium solani) of chick pea. Life Science J., 11: 99-102.

Rahman Z, AHM Mafuzul Haque, MA Zaman, MF Amin and AK Das, 2012. Efficacy of two fungicides and two botanicals to control foot and root rot disease (Sclerotium rolfsii) of cowpea. Bangladesh J. Plant Pathol., 28: 29-32.

Sarkar SK and SC Saxena, 2005. Field efficacy of seed dressing fungicides on emergence, survival and seedling vigour of sunhemp (Crotalaria juncea L.). Seed Res., 33: 100-102.

Shah R and JP Jain, 1993. Seed mycoflora of mustard and its control. Indian J. Mycol., 23: 291-295.

Tanweer A, 1982. Effect of new fungicide on viability of rice and sorghum seeds. Pestology, 6: 9-10.

Utobo EB, EN Ogbodo and AC Nwogbaga, 2011. Seed borne mycota associated with rice and their influence on growth of Abakaliki, Southeast agro-ecology, Nigeria. Libiyan Agric. Res. Cen. J. Inter., 2: 79-84.

Windham AS and MT Windham, 2004. Chemical control of plant diseases. In: Plant Pathology. Concepts and Lab Exercises. CRC Pub.USA. 